Papan Partikel dari Serbuk Kayu dan Limbah Penyulingan Kulit Kayu Gemor ....Budi Tri Cahyana

\title{
PAPAN PARTIKEL DARI SERBUK KAYU DAN LIMBAH PENYULINGAN KULIT KAYU GEMOR (Alseodaphne spp.)
}

\author{
Particle Board for Wood Sawdust and \\ Gemor Bark (Alseodaphne spp) Distillation Waste \\ Budi Tri Cahyana \\ Balai Riset dan Standardisasi Industri \\ Jl. P. Batur Barat No.2. Telp./Fax. 0511-4772461/0511-4772115 Banjarbaru \\ E-mail : baristand.banjarbaru@gmail.com \\ Diterima, 13 Agustus 2013, disetujui 06 Nopember 2013
}

\begin{abstract}
ABSTRAK
Pemanfaatan limbah penyulingan kulit kayu gemor (Alseodaphne spp) untuk papan partikel telah dilakukan. Tujuan penelitian ini untuk mengetahui sifat fisik mekanik papan partikel dari campuran serbuk gergajian kayu dengan limbah penyulingan kulit kayu gemor. Bahan baku yang digunakan meliputi serbuk gergajian kayu dan limbah penyulingan kulit kayu gemor. Limbah penyulingan kulit kayu gemor dihaluskan dan disaring dengan ukuran 16. Perekat yang digunakan yaitu kanji dan PVAc. Variasi komposisi campuran partikel serbuk gergajian kayu dengan limbah penyulingan kulit kayu gemor 50\%: 50\%, 60\% : 40\%., 70\% : 30\% dan kosentrasi perekat 5\%. Hasil penelitian menunjukkan nilai rata-rata tertinggi untuk keteguhan patah $\left(27,55 \mathrm{~kg} / \mathrm{cm}^{2}\right)$ diperoleh pada perlakuan perbandingan serbuk gergajian kayu dan limbah hasil penyulingan kulit kayu gemor $70 \%: 30 \%$ dengan bahan perekat kanji dengan nilai kerapatan $0,75 \mathrm{gr} / \mathrm{cm}^{3}$. Nilai rata-rata tertinggi keteguhan lentur $\left(351,50 \mathrm{~kg} / \mathrm{cm}^{2}\right)$ dihasilkan pada perlakuan komposisi 60\%: 40\% dengan bahan perekat kanji dan nilai kerapatan $0,69 \mathrm{gr} / \mathrm{cm}^{3}$. Nilai rata-rata tertinggi keteguhan tarik $\left(4,11 \mathrm{~kg} / \mathrm{cm}^{2}\right)$ diperoleh pada perlakuan komposisi $50 \%: 50 \%$ dengan bahan perekat kanji dengan nilai kerapatan $0,79 \mathrm{gr} / \mathrm{cm}^{3}$.
\end{abstract}

Kata kunci : serbuk gergajian kayu, limbah penyulingan, kulit kayu gemor, papan partikel

\begin{abstract}
Utilization of gemor bark (Alseodaphne spp) distillation waste for particle board had been carried out. The aim of this research was physical mechanical from wood sawdust waste mixed with gemor bark distillation waste which properties physically and mechanically meet quality requirements. The raw materials used were sawdust mixed with gemor bark distillation waste which mashed16 mesh and the adhesive used were starch and PVAC. Composition variety of the mixture of wood sawdust waste particles and gemor bark distillation waste particle 50\%: 50\%, 60\%: 40\%., 70\%: 30\% with 5\% adhesive. The results showed that highest average of modulus of rupture $\left(27,55 \mathrm{~kg} / \mathrm{cm}^{2}\right)$ was obtained in 70\% : 30\% comparison of sawdust and gemor bark distillation waste with starch adhesive (a3b1) and the density average was $0.75 \mathrm{gr} / \mathrm{cm} 3$. The highest average of modulus of elasticity $\left(351,50 \mathrm{~kg} / \mathrm{cm}^{2}\right)$ was in composition of $60 \%: 40 \%$ with starch adhesive (a2b1) and the density average was $0.69 \mathrm{gr} / \mathrm{cm} 3$. The highest average of tensile strength $\left(4,11 \mathrm{~kg} / \mathrm{cm}^{2}\right)$ was obtained in composition of $50 \%: 50 \%$ with starch adhesive and the density average was $0.79 \mathrm{gr} / \mathrm{cm} 3$.
\end{abstract}

Keywords: sawdust wood, distillation waste, gemor bark, particle board

\section{PENDAHULUAN}

Limbah dari kegiatan industri sisa potongan yang tidak termanfaatkan. pengolahan kayu menghasilkan berupa Selama ini limbah dikelola dengan konsep 
buang begitu saja, buang bakar (dengan incenerator atau dibakar begitu saja), gali tutup, ternyata tidak memberikan solusi yang baik dalam pemanfaatan limbah. (www.tentangkayu.com/2007/12/limbah dari-industri-kayu.html).

Di Kalimantan Selatan, pada tahun 2001 produksi kayu gergajian mencapai $2.18154,939 \mathrm{~m} 3$ dan pada tahun 2002 mengalami penurunan, yaitu menjadi 357.513.04 m3 (Dinas Kehutanan Propinsi Kalimantan Selatan, 2003). Penurunan produksi diperkirakan karena keberadaan potensi alam semakin berkurang. Dalam industri penggergajian kayu dihasilkan limbah kayu dengan berbagai komposisi yaitu sebetan kayu $22 \%$, potongan kayu $8 \%$ dan serbuk kayu $10 \%$ dari volume bahan baku kayu gelondongan (Purwanto, 2011).

Di antara hasil hutan bukan kayu yang cukup berperan sebagai komoditas potensial adalah kulit kayu gemor. Kulit batang gemor berasal dari pohon gemor (Alseodaphne spp) termasuk dalam famili Lauraceae dan banyak tumbuh di daerah hutan hujan dataran rendah dan hidupnya berkelompok di hutan Kalimantan Selatan dan Kalimantan Tengah. Menurut Violet (2007), produksi kulit kayu gemor di Kalimantan tengah. Pohon gemor berdiameter $30 \mathrm{~cm}$ dapat menghasilkan kulit kayu sebanyak 250 - 300 kg/pohon dan diameter $40 \mathrm{~cm}$ dapat menghasilkan kulit sebanyak 500-600 kg/pohon dalam kondisi basah. Hasil penyulingan kulit kayu gemor berupa minyak atsiri yang biasanya sebagai campuran untuk anti nyamuk. Dari hasil penyulingan kulit kayu gemor menghasilkan limbah padat yang dapat digunakan sebagai produk berupa papan partikel yang dapat dicampur dengan limbah serbuk gergajian kayu. Alternatif pemanfaatan limbah dari penyulingan kulit kayu gemor dapat berupa produk papan partikel atau papan buatan dengan mencampur perekat kemudian dilakukan proses pengempaan / pemadatan. Tujuan penelitian ini untuk memperoleh papan partikel dari campuran limbah serbuk gergajian kayu dengan limbah penyulingan kulit kayu gemor yang memiliki sifat fisik dan mekanik yang memenuhi syarat mutu.

\section{BAHAN DAN METODE}

Bahan yang digunakan dalam penelitian ini meliputi limbah serbuk gergajian kayu dari pengusaha penggergajian kayu, dan limbah hasil penyulingan kulit kayu gemor. Bahan perekat yang digunakan adalah kanji dan PVAc. Peralatan yang digunakan antara lain timbangan, oven, cetakan, mesin press (hot press), Universal Testing Machine (UTM), aluminium foil dan jangka sorong (caliper). Bahan Baku (partikel dari serbuk gergajian kayu dan limbah penyulingan kulit kayu gemor) dihaluskan dan disaring dengan ukuran 16 mesh kemudian partikel tersebut dikeringkan sampai kadar air sekitar 5\%. Partikel serbuk gergajian kayu dengan limbah penyulingan kulit kayu gemor masing-masing dicampur dengan perekat kanji maupun perekat PVAc hingga merata. Variasi komposisi campuran partikel serbuk gergajian kayu dengan partikel limbah penyulingan kulit kayu gemor 50\% : 50\% (a1), 60\% : 40\%. (a2), 70\% : 30\% (a3) serta variasi perekat yaitu kanji (b1) dan PVAc (b2) dengan konsentrasi 5\%. Partikel yang telah tercampur merata dengan perekat dimasukkan dalam cetakan ukuran 25 × 25 $\mathrm{cm}$ yang telah diberi alas aluminium foil, ketebalan papan partikel $1,5 \mathrm{~cm}$. Pencetakan papan partikel dengan press dingin selama 5 menit dengan tekanan 200 $\mathrm{kgf} / \mathrm{cm}^{2}$ dan press panas pada suhu $100^{\circ} \mathrm{C}$ selama 15 menit. Papan partikel dikeluarkan dari cetakan kemudian dilakukan pengkondisian / pendinginan.

Data yang diperoleh dianalisa dengan menggunakan Rancangan Acak Lengkap (RAL) faktorial dengan ulangan masingmasing perlakuan sebanyak 3 (tiga) kali. Pengujian sifat fisik dan mekanik yang dilakukan meliputi pengujian kadar air, kerapatan, pengembangan tebal, keteguhan patah (MoR), keteguhan lentur (MoE), keteguhan tarik berdasarkan Standar Nasional Indonesia (SNI 03-21052006) tentang papan partikel.

\section{HASIL DAN PEMBAHASAN}

Nilai rata-rata hasil pengujian sifat fisik papan partikel limbah serbuk gergajian 
kayu dengan limbah penyulingan kulit kayu gemor yang meliputi kadar air, kerapatan, pengembangan tebal dapat dilihat pada Tabel 1.

\subsection{Kadar Air}

Berdasarkan pada Tabel 1. dapat dikemukakan nilai kadar air rata-rata pada papan serbuk gergajian kayu dengan limbah penyulingan kulit kayu gemor berkisar antara 10,50 - 11,78\% dimana kadar air papan partikel hasil penelitian memenuhi SNI 03-2105-2006 yang mempersyaratkan kadar air papan partikel tidak diperkenankan lebih dari $14 \%$.

Untuk mengetahui adanya pengaruh perlakuan terhadap kadar air papan partikel yang dihasilkan dari serbuk gergajian kayu dengan limbah penyulingan kulit kayu gemor, maka dilakukan analisis sidik keragaman seperti pada Tabel 2 . Berdasarkan uji keragaman Tabel 2. menunjukkan perlakuan, variasi komposisi campuran papan partikel serbuk gergajian kayu dan limbah penyulingan kulit kayu gemor 50\% : 50\% (a1), 60\% : 40\% (a2), 70\% : 30\% (a3) dan interaksi berpengaruh sangat nyata terhadap kadar air. Bahan perekat kanji (b1), PVAc (b2) dengan kadar perekat $5 \%$ tidak berpengaruh nyata terhadap kadar air. Menurut Bowyer et al. (1996) bahwa nilai kadar air papan partikel dipengaruhi oleh kadar air partikel sebelum dikempa, jumlah air terkandung dalam perekat dan jumlah uap air yang keluar dari dalam papan partikel saat dikempa.

Untuk mengetahui perbedaan masingmasing variasi perlakuan kadar air dari papan partikel serbuk gergajian kayu dan limbah penyulingan kulit kayu gemor dilakukan uji beda seperti pada Tabel 3 . Dari hasil uji beda Tabel 3. menunjukkan bahwa hampir semua perlakuan menunjukkan perbedaan yang sangat nyata kecuali pada perlakuan a1b2 dengan a3b1, a1b1 dengan a1b2, a2b2 dengan $a 1 b 1, a 3 b 2$ dan a2b2, a2b1 dengan a1b1 dan a3b2 serta a3b2 dengan a1b1.

\subsection{Kerapatan}

Berdasarkan pada Tabel 1. dapat dikemukakan nilai kerapatan rata-rata pada papan partikel serbuk gergajian kayu dan limbah penyulingan kulit kayu gemor berkisar antara 0,55-0,79 $\mathrm{gr} / \mathrm{cm}^{3}$. Nilai kerapatan terendah $0,55 \mathrm{gr} / \mathrm{cm}^{3}$ pada serbuk gergajian kayu dengan limbah penyulingan kulit kayu gemor 50\% : 50\% dengan perekat kanji (a1b2). Nilai kerapatan tertinggi $0,79 \mathrm{gr} / \mathrm{cm}^{3}$ pada serbuk gergajian kayu dengan limbah penyulingan kulit kayu gemor 50\%: 50\% dengan perekat kanji (a1b1). Menurut Santoso (2003), papan partikel berkerapatan sedang bekisar antara 0,59$0,80 \mathrm{gr} / \mathrm{cm}^{3}$. Papan partikel yang dihasilkan berkerapatan sedang karena suhu kempa yang digunakan adalah $100^{\circ} \mathrm{C}$. Menurut Jufriah et al (2007), pada suhu rendah $\left(100^{\circ} \mathrm{C}\right)$, proses pematangan perekat kurang berjalan dengan baik, sehingga pada saat tekanan dibuka, papan partikel mengalami kembang balik (spring back) cukup besar sehingga kerapatan papan partikel menurun.

Untuk mengetahui adanya pengaruh perlakuan terhadap kerapatan papan partikel yang dihasilkan dari serbuk gergajian kayu dan limbah penyulingan kulit kayu gemor, maka dilakukan analisis sidik keragaman seperti pada Tabel 4. Berdasarkan uji keragaman Tabel 4. menunjukkan perlakuan, variasi komposisi campuran papan partikel serbuk gergajian kayu dengan limbah penyulingan kulit kayu gemor 50\% : 50\% (a1), 60\% : 40\% (a2), $70 \%$ : 30\% (a3) dan bahan perekat kanji (b1), PVAc (b2) dengan kadar perekat $5 \%$ serta interaksi berpengaruh sangat nyata terhadap kerapatan.

Untuk mengetahui perbedaan masingmasing perlakuan kerapatan dari papan partikel limbah serbuk gergajian kayu dengan limbah penyulingan kulit kayu gemor dilakukan uji beda seperti pada Tabel 5. Dari hasil uji beda Tabel 5 . menunjukkan bahwa variasi perlakuan campuran komposisi papan partikel serbuk gergajian kayu dan limbah penyulingan kulit kayu gemor dengan variasi perekat berbeda sangat nyata terhadap kerapatan kecuali $\mathrm{a} 2 \mathrm{~b} 2$ dengan $\mathrm{a} 2 \mathrm{~b} 1$ dan $\mathrm{a} 3 \mathrm{~b} 2$ dengan a3b1.

\subsection{Pengembangan Tebal}

Berdasarkan pada Tabel 1. dapat dikemukakan nilai pengembangan tebal 
rata-rata pada papan partikel serbuk gergajian kayu dan limbah penyulingan kulit kayu gemor berkisar antara 9,42 $21,97 \%$ untuk perekat kanji dan 17,85 $32,26 \%$ untuk perekat PVAc. Pengembang an tebal papan partikel menggunakan perekat PVAc lebih besar daripada perekat kanji. Hal ini dikarenakan sifat perekat PVAc mempunyai gugus-gugus atom aktif sehingga dapat mengikat bahan-bahan lain dengan cara hydrogen bonding maupun adsorpsi secara kimia sehingga jika papan partikel dengan perekat PVAc direndam, PVAc akan terhidrolisa oleh air sehingga ikatan antar partikel semakin lemah sehingga dimensi papan lebih mudah terdegradasi. Nilai pengembangan tebal terendah $9,42 \%$ pada campuran komposisi limbah serbuk gergajian kayu dengan limbah penyulingan kulit kayu gemor pada perlakuan 50\% : 50\% dengan perekat kanji (a1b1). Pengembangan tebal papan partikel dalam penelitian ini tidak memenuhi persyaratan SNI karena pengembangan tebal lebih dari $12 \%$. Tingginya nilai pengembangan tebal yang dihasilkan karena sifat bahan papan partikel makin tinggi kerapatannya maka makin tinggi pula kecenderungan papan partikel kembali mengalami perubahan dimensi awal. Untuk papan partikel berkerapatan tinggi mempunyai rongga kosong yang sedikit maka lebih banyak air yang memasuki struktur partikel kayu (Abdurachaman, 2011). Di sisi lain, Jufriah et al (2007) menyatakan bahwa pada temperatur kempa yang rendah $\left(100^{\circ} \mathrm{C}\right)$, pematangan perekat belum sempurna dan menghasilkan ikatan partikel dan perekat yang lemah, sehingga jika papan partikel direndam, akan mengalami pengembangan tebal yang lebih besar dibanding dengan temperature kempa di atas $100^{\circ} \mathrm{C}$. Menurut S. Ruhendi (2011), semakin banyak air yang diabsorbsi dan memasuki struktur partikel maka semakin banyak perubahan dimensi papan partikel.

Untuk mengetahui adanya pengaruh perlakuan terhadap pengembangan tebal papan partikel yang dihasilkan dari limbah serbuk gergajian kayu dengan limbah penyulingan kulit kayu gemor, maka dilakukan analisis sidik keragaman seperti pada Tabel 6. Berdasarkan uji keragaman Tabel 6. menunjukkan perlakuan, komposisi campuran papan partikel serbuk gergajian kayu dan limbah penyulingan kulit kayu gemor, bahan perekat kanji (b1), PVAc (b2) dan interaksi berpengaruh sangat nyata terhadap pengembangan tebal.

Untuk mengetahui perbedaan masing masing variasi perlakuan pengembangan tebal papan partikel serbuk gergajian kayu dan limbah penyulingan kulit kayu gemor dilakukan uji beda seperti pada Tabel 7 . Dari hasil uji beda Tabel 7. menunjukkan bahwa variasi perlakuan campuran komposisi papan partikel serbuk gergajian kayu dan limbah penyulingan kulit kayu gemor berbeda sangat nyata terhadap pengembangan tebal. Perlakuan a3b1 berbeda nyata dengan a2b1 dan antara a2b1 dengan a3b2 tidak menunjukkan perbedaan yang nyata.

\subsection{Keteguhan Patah (MoR)}

Nilai rata-rata hasil pengujian sifat mekanik papan parikel dari serbuk gergajian kayu dan limbah penyulingan kulit kayu gemor yang meliputi keteguhan patah (MoR), keteguhan lentur (MoE) dan keteguhan tarik dapat dilihat pada Tabel 8 .

Nilai rata-rata keteguhan patah pada Tabel 8. komposisi serbuk gergajian kayu dan limbah penyulingan kulit kayu gemor berkisar antara $11,03-27,55 \mathrm{~kg} / \mathrm{cm}^{2}$. Nilai rata-rata terendah keteguhan patah diperoleh pada perlakuan komposisi serbuk gergajian kayu dan limbah penyulingan kulit kayu gemor 50\% : 50\% bahan perekat PVAc (a1b2) . Nilai rata-rata tertinggi keteguhan patah dihasilkan pada perlakuan komposisi serbuk gergajian kayu dan limbah penyulingan kulit kayu gemor 70\% : 30\% bahan perekat kanji (a3b1).

Untuk mengetahui adanya pengaruh perlakuan terhadap keteguhan patah (MoR) papan partikel yang dihasilkan dari serbuk gergajian kayu dan limbah penyulingan kulit kayu gemor, maka dilakukan analisis sidik keragaman seperti pada Tabel 9. Berdasarkan uji keragaman Tabel 9. menunjukkan bahwa perlakuan, komposisi campuran papan partikel dan bahan perekat berpengaruh sangat nyata 
terhadap keteguhan patah, sedangkan interaksi keduanya berpengaruh nyata terhadap keteguhan patah.

Untuk mengetahui perbedaan masingmasing variasi perlakuan keteguhan patah dari papan partikel serbuk gergajian kayu dan limbah penyulingan kulit kayu gemor dilakukan uji beda seperti pada Tabel 10 . Dari hasil uji beda

Tabel 10. menunjukkan bahwa papan partikel serbuk gergajian kayu dan limbah penyulingan kulit kayu gemor dengan komposisi perlakuan 50\%: 50\% perekat PVAc (a1b2) berbeda sangat nyata dengan komposisi perlakuan $70 \%$ : 30\% perekat kanji (a3b1) dan berbeda nyata $70 \%: 30 \%$ perekat PVAc (a3b2), 60\% : $40 \%$ perekat kanji (a2b1), 60\% : 40\% perekat PVAc (a2b2) dan 50\% : 50\% perekat kanji (a1b1). Komposisi perlakuan 70\% : 30\% perekat kanji (a3b1) berbeda nyata dengan komposisi perlakuan 50\% : 50\% perekat kanji (a1b1), 60\% : 40\% perekat PVAc (a2b2) dan 60\% : 40\% perekat kanji (a2b1).

\subsection{Keteguhan Lentur (MoE)}

Menurut Maloney (1993) dalam Ema Ratri J.W. (2011) bahwa Modulus of Elasticity (MoE) adalah ukuran kemampuan material dalam menahan perubahan bentuk sampai batas proporsi yang menunjukkan sifat elastisitas bahan. Pada nilai rata-rata keteguhan lentur pada Tabel 8. komposisi papan partikel dari limbah serbuk gergajian kayu dengan limbah penyulingan kulit kayu gemor berkisar antara 137,46 - 351,50 kg/ $\mathrm{cm}^{2}$. Nilai rata-rata terendah keteguhan lentur diperoleh pada perlakuan komposisi serbuk gergajian kayu dan limbah penyulingan kulit kayu gemor $50 \%$ : $50 \%$ bahan perekat kanji (a1b1). Nilai rata-rata tertinggi keteguhan lentur dihasilkan pada perlakuan komposisi serbuk gergajian kayu dan limbah penyulingan kulit kayu gemor 60\% : 40\% bahan perekat kanji (a2b1).

Untuk mengetahui adanya pengaruh perlakuan terhadap keteguhan lentur (MoE) papan partikel yang dihasilkan dari serbuk gergajian kayu dan limbah penyulingan kulit kayu gemor, maka dilakukan analisis sidik keragaman seperti pada Tabel 11. Berdasarkan uji keragaman Tabel 11. menunjukkan bahwa komposisi campuran papan partikel berpengaruh nyata terhadap keteguhan lentur, sedangkan perlakuan, bahan perekat dan interaksi keduanya tidak berpengaruh nyata terhadap keteguhan lentur. Hal ini disebabkan komposisi serbuk gergajian kayu dan limbah penyulingan kulit kayu gemor yang digunakan memberikan pengaruh terhadap papan partikel yang dihasilkan.

Untuk mengetahui perbedaan masing masing variasi perlakuan komposisi terhadap keteguhan lentur dari papan partikel serbuk gergajian kayu dan limbah penyulingan kulit kayu gemor dilakukan uji beda seperti pada Tabel 12. Dari hasil uji beda Tabel 12. menunjukkan bahwa papan partikel serbuk gergajian kayu dengan limbah penyulingan kulit kayu gemor dengan komposisi perlakuan $\quad 50 \%$ : $50 \%$ (a1) berbeda nyata dengan komposisi perlakuan $70 \%$ : 30\% (a3). Hal ini disebabkan komposisi serbuk gergajian kayu dan limbah penyulingan kulit kayu gemor mempengaruhi terhadap keteguhan lentur papan partikel.

\subsection{Keteguhan Tarik}

Menurut Bowyer et al. 1996 bahwa keteguhan tarik tegak lurus serat permukaan panel papan partikel menunjukkan kekuatan ikatan antar partikel, pencampuran, pembentukan lembaran dan proses pengempaan. Pada nilai rata-rata keteguhan tarik pada Tabel 3.8. serbuk gergajian kayu dan limbah penyulingan kulit kayu gemor berkisar antara $1,09-4,36 \mathrm{~kg} / \mathrm{cm}^{2}$. Nilai rata-rata terendah keteguhan tarik pada perlakuan komposisi serbuk gergajian kayu dan limbah penyulingan kulit kayu gemor 50\% : 50\% bahan perekat PVAc (a1b2). Nilai rata-rata tertinggi keteguhan tarik pada perlakuan komposisi serbuk gergajian kayu dan limbah penyulingan kulit kayu gemor $50 \%$ : 50\% (a1b1) bahan perekat kanji. Keteguhan tarik papan partikel yang dibuat dari limbah penyulingan kulit kayu gemor dan serbuk gergajian kayu memenuhi syarat $\mathrm{SNI}$ yaitu lebih besar $0,6 \mathrm{~kg} / \mathrm{cm}^{2}$. 
Untuk mengetahui adanya pengaruh perlakuan terhadap keteguhan tarik papan partikel yang dihasilkan dari serbuk gergajian kayu dan limbah penyulingan kulit kayu gemor, maka dilakukan analisis sidik keragaman seperti pada Tabel 13. Berdasarkan uji keragaman Tabel 13. menunjukkan bahwa perlakuan, komposisi campuran papan partikel, bahan perekat dan interaksi keduanya berpengaruh sangat nyata terhadap keteguhan tarik.

Untuk mengetahui perbedaan masingmasing variasi perlakuan terhadap keteguhan tarik dari papan partikel dari serbuk gergajian kayu dan limbah penyulingan kulit kayu gemor dilakukan uji beda seperti pada Tabel 14. Dari hasil uji beda Tabel 14. menunjukkan hampir semua variasi perlakuan berpengaruh nyata dan sangat nyata terhadap keteguhan tarik papan partikel kecuali antara a1b1 dengan a3b1, a2b1 dengan a2b2 dan a2b2 dengan a1b2.

\section{KESIMPULAN}

Nilai kerapatan tertinggi $0,79 \mathrm{gr} / \mathrm{cm}^{3}$ pada serbuk gergajian kayu dan limbah penyulingan kulit kayu gemor 50\%: 50\% dengan perekat kanji. Nilai tertinggi keteguhan patah dihasilkan pada perlakuan komposisi serbuk gergajian kayu dan limbah penyulingan kulit kayu gemor 70\% : 30\% dengan bahan perekat kanji. Nilai tertinggi keteguhan lentur diperoleh pada perlakuan komposisi serbuk gergajian kayu dan limbah penyulingan kulit kayu gemor 60\% : 40\% dengan bahan perekat kanji. Nilai tertinggi keteguhan tarik diperoleh pada perlakuan komposisi serbuk gergajian kayu dan limbah penyulingan kulit kayu gemor 50\% : 50\% dan bahan perekat kanji.

\section{DAFTAR PUSTAKA}

1. Anonim, 2007. www.tentangkayu.com/ 2007/12/limbah-dari-industri-kayu.html. Diaskes tanggal 20 Juni 2011.

2. Abdurachman dan Nurwati Hadjib. 2011. Sifat Papan Partikel dari Kayu Kulit Manis (Cinnamomum burmanii
$B L)$. Bogor : Pusat Penelitian dan Pengembangan Keteknikan Kehutanan dan Pengolahan Hasil Hutan Bogor.

3. Badan Standardisasi Nasional.2006. Papan Partikel. Standar Nasional Indonesia (SNI) 03-2105-2006.

4. Dinas Kehutanan Propinsi Kalimantan Selatan. 2003. Statistik Kehutanan 2002 Propinsi Kalimantan Selatan.

5. Departemen Kehutanan 2004. Pemanfaatan Limbah Kayu. Bahan Ekspos dengan Menteri Kehutanan. Bogor : Pusat Penelitian dan Pengembangan Teknologi Hasil Hutan. Badan Litbang Departemen Kehutanan.

6. Djoko Purwanto, 2011. Pembuatan Balok dan Papan dari Limbah Industri Kayu. Jurnal Riset Industri. Baristand Industri Banjarbaru. 5 (1): 13-20.2011.

7. Ema Ratri Kartika J. W. 2011. Kualitas Papan Partikel Dari Log Diameter Kecil. Bogor : Fakultas Kehutanan Institut Pertanian Bogor.

8. Jufriah, Wagiman, S., Masrinah. 2007. Sifat Fisika dan Mekanika Papan Partikel dari Batang Sawit (Elaeis Gueneensis, Jaeq) dengan Variasi Temperatur Kempa Panas. RIMBA Kalimantan Fakultas Kehutanan Universitas Mulawarman. 2 (2) : 106114.2007.

9. Haygreen, J.G. dan J.L. Bowyer. 1996. Hasil Hutan dan IImu Kayu, Suatu Pengantar. (terjemahan Soetjipto A.H). Yogyakarta : Gadjah Mada University Press.

10. Paribroto Sutigno. Departemen Kehutanan. 1982. Sifat-sifat Papan Partikel Tiga Jenis Kayu. Jakarta : Duta Rimba. 
11. Paribotro S. dan Adi Santoso. 1991. Pengaruh Penambahan Urea dan Amonium Karbon Pada Perekat UF Terhadap Emisi Formaldehida dan Sifat Fisik Mekanik Papan Partikel. Jurnal Litbang Hasil Hutan. 9 (2).

12. Santoso, A dan Jasni. 2003. Daya Tahan Garis Rekat LRF pada Kayu Lamina Mani terhadap Serangan Rayap Kayu Kering. J.Ilmu dan Teknologi Kayu Tropis. 1 (1) : 26-37.

13. S. Ruhendi dan Erwinsyah P. 2011. Sifat Fisik dan Mekanis Papan Partikel dari Batang dan Cabang Kayu Jabon (Anthocephalus cadamba Miq). Jurnal IImu dan Tehnologi Hasil Hutan. 4(1) : 14-21. Departemen Hasil Hutan Fakultas Kehutanan IPB. Bogor

14. Violet Hatta, 2007. Pemanfaatan Hasil Hutan Bukan Kayu Perlu Kearifan. Banjarbaru : Fakultas Kehutanan Universitas Lambung Mangkurat Banjarbaru. 
Tabel 1. Nilai Rata-rata Sifat Fisik Papan partikel Serbuk Gergajian Kayu dan Limbah penyulingan Kulit Kayu Gemor

\begin{tabular}{|c|c|c|c|c|c|c|c|}
\hline \multirow{3}{*}{ No. } & \multirow{3}{*}{$\begin{array}{c}\text { Komposisi Serbuk } \\
\text { Gergajian Kayu Dan } \\
\text { Limbah Penyulingan } \\
\text { Kulit Kayu Gemor (\%) }\end{array}$} & \multicolumn{6}{|c|}{ Parameter Uji } \\
\hline & & \multicolumn{2}{|c|}{$\begin{array}{c}\text { Kadar Air } \\
(\%)\end{array}$} & \multicolumn{2}{|c|}{$\begin{array}{c}\text { Kerapatan } \\
\left(\mathrm{gr} / \mathrm{cm}^{3}\right)\end{array}$} & \multicolumn{2}{|c|}{ Pengembangan Tebal (\%) } \\
\hline & & $\begin{array}{l}\text { Kanji } \\
\text { (b1) }\end{array}$ & $\begin{array}{l}\text { PVAc } \\
\text { (b2) }\end{array}$ & $\begin{array}{l}\text { Kanji } \\
\text { (b1) }\end{array}$ & $\begin{array}{l}\text { PVAc } \\
\text { (b2) }\end{array}$ & $\begin{array}{l}\text { Kanji } \\
\text { (b1) }\end{array}$ & $\begin{array}{l}\text { PVAc } \\
\text { (b2) }\end{array}$ \\
\hline 1. & $\begin{array}{l}50: 50 \\
\text { (a1) }\end{array}$ & 11,42 & 10,88 & 0,79 & 0,55 & 9,42 & 26,50 \\
\hline 2. & $\begin{array}{l}60: 40 \\
(\mathrm{a} 2)\end{array}$ & 11,78 & 11,80 & 0,69 & 0,68 & 18,62 & 32,26 \\
\hline 3. & $\begin{array}{l}70: 30 \\
(\mathrm{a} 3)\end{array}$ & 10,50 & 11,68 & 0,75 & 0,73 & 21,97 & 17,85 \\
\hline
\end{tabular}

Tabel 2. Analisis Sidik Keragaman Kadar Air Papan Partikel Serbuk Gergajian Kayu dan Limbah Penyulingan Kulit Kayu Gemor

\begin{tabular}{lllllll}
\hline $\begin{array}{c}\text { Sumber } \\
\text { Keragaman }\end{array}$ & DB & $\begin{array}{l}\text { Jumlah } \\
\text { Kuadrat }\end{array}$ & $\begin{array}{l}\text { Kuadrat } \\
\text { Tengah }\end{array}$ & F Hitung & \multicolumn{2}{c}{ F table } \\
\hline Komposisi (A) & 2 & 1,806 & 0,903 & $7,173^{*}$ & 3,88 & 6,93 \\
\hline Perekat (B) & 1 & 0,220 & 0,220 & 1,747 & 4,75 & 9,33 \\
\hline Interaksi (AB) & 2 & 2,313 & 1,156 & 9,184 & 3,88 & 6,93 \\
\hline Galat & 12 & 1,511 & 0,126 & & & \\
\hline
\end{tabular}

Keterangan : ") berpengaruh sangat nyata

Tabel 3. Uji Beda Harga Rata-rata Kadar Air Papan Partikel Serbuk Gergajian Kayu dan Limbah Penyulingan Kulit Kayu Gemor

\begin{tabular}{|c|c|c|c|c|c|c|c|}
\hline \multirow{2}{*}{\multicolumn{2}{|c|}{$\begin{array}{c}\text { Faktor AB } \\
\text { Nilai Tengah (\%) }\end{array}$}} & a2b2 & $\mathrm{a} 2 \mathrm{~b} 1$ & a3b2 & a1b1 & $\mathrm{a} 1 \mathrm{~b} 2$ & a3b1 \\
\hline & & 11,80 & 11,78 & 11,68 & 11,42 & 10,88 & 10,50 \\
\hline & a3b1 & 1,30 & 1,28 & 1,18 & 0,92 & 0,38 & 0 \\
\hline \multirow[t]{5}{*}{ Nilai Beda dengan } & $a 1 b 2$ & $0,92^{* *}$ & $0,90^{* *}$ & $0,80^{* *}$ & 0,54 & 0 & \\
\hline & $a 1 b 1$ & 0,38 & 0,36 & 0,26 & 0 & & \\
\hline & $a 3 b 2$ & 0,12 & 0,10 & 0 & & & \\
\hline & $\mathrm{a} 2 \mathrm{~b} 1$ & 0,02 & 0 & & & & \\
\hline & $\mathrm{a} 2 \mathrm{~b} 2$ & 0 & & & & & \\
\hline \multicolumn{4}{|c|}{$\operatorname{LSD}(0,05)=0,631$} & & LSD & $01)=0$, & \\
\hline
\end{tabular}

Keterangan : **) berbeda sangat nyata

Tabel 4. Analisis Sidik Keragaman Kerapatan Papan Partikel Serbuk Gergajian Kayu dan Limbah Penyulingan Kulit Kayu Gemor

\begin{tabular}{lllllll}
\hline Sumber & DB & Jumlah & Kuadrat & F Hitung & F table & \\
\hline Keragaman & & Kuadrat & Tengah & & $5 \%$ & $1 \%$ \\
Komposisi (A) & 2 & 0.016 & 0.0079 & $30.804^{* *}$ & 3.88 & 6.93 \\
Perekat (B) & 1 & 0.036 & 0.0356 & $139.130^{* *}$ & 4.75 & 9.33 \\
Interaksi (AB) & 2 & 0.049 & 0.0246 & $96.283^{* *}$ & 3.88 & 6.93 \\
Galat & 12 & 0.003 & 0.0003 & & & \\
\hline
\end{tabular}

Keterangan : ') berpengaruh sangat nyata 
Tabel 5. Uji Beda Harga Rata-rata Kerapatan Papan Partikel Serbuk Gergajian Kayu dan Limbah Penyulingan Kulit Kayu Gemor

\begin{tabular}{|c|c|c|c|c|c|c|c|}
\hline \multicolumn{2}{|l|}{ Faktor AB } & $\mathrm{a} 1 \mathrm{~b} 2$ & $\mathrm{a} 2 \mathrm{~b} 2$ & $\mathrm{a} 2 \mathrm{~b} 1$ & a3b2 & $\mathrm{a} 3 \mathrm{~b} 1$ & $\mathrm{a} 1 \mathrm{~b} 1$ \\
\hline \multicolumn{2}{|c|}{ Nilai Tengah $\left(\mathrm{gr} / \mathrm{cm}^{3}\right)$} & 0,55 & 0,68 & 0,69 & 0,73 & 0,75 & 0,79 \\
\hline & a1b1 & 0,24 & 0,11 & 0,10 & 0,060 & 0,04 & 0 \\
\hline \multirow[t]{5}{*}{ Nilai Beda dengan } & $a 3 b 1$ & $0,20^{n \pi}$ & $0,07^{\times *}$ & 0,06 & 0,020 & 0 & \\
\hline & a3b2 & $0,18^{* *}$ & $0,05^{* *}$ & $0,04^{* *}$ & 0 & & \\
\hline & $a 2 b 1$ & $0,14^{\mathrm{*x}}$ & 0,01 & 0 & & & \\
\hline & $\mathrm{a} 2 \mathrm{~b} 2$ & $0,13^{* *}$ & 0 & & & & \\
\hline & $\mathrm{a} 1 \mathrm{~b} 2$ & 0 & & & & & \\
\hline
\end{tabular}

Keterangan : ${ }^{* *}$ ) berbeda sangat nyata

Tabel 6. Analisa Sidik Keragaman Pengembangan Tebal Papan Partikel Serbuk Gergajian Kayu Dan Limbah Penyulingan Kulit Kayu Gemor

\begin{tabular}{|c|c|c|c|c|c|c|}
\hline Sumber & DB & Jumlah & Kuadrat & F Hitung & \multicolumn{2}{|c|}{ F table } \\
\hline Keragaman & & Kuadrat & Tengah & & $5 \%$ & $1 \%$ \\
\hline Komposisi (A) & 2 & 180,605 & 90,302 & $33,455^{* *}$ & 3.88 & 6.93 \\
\hline Perekat (B) & 1 & 354,135 & 354,135 & $131,198^{* *}$ & 4.75 & 9.33 \\
\hline Interaksi $(\mathrm{AB})$ & 2 & 388,359 & 194,179 & $71,938^{x *}$ & 3.88 & 6.93 \\
\hline Galat & 12 & 32,391 & 2,699 & & & \\
\hline
\end{tabular}

Keterangan : ${ }^{* *}$ ) berpengaruh sangat nyata

Tabel 7. Uji Beda Harga Rata-rata Pengembangan Tebal Papan Partikel Serbuk Gergajian Kayu Dan Limbah Penyulingan Kulit Kayu Gemor

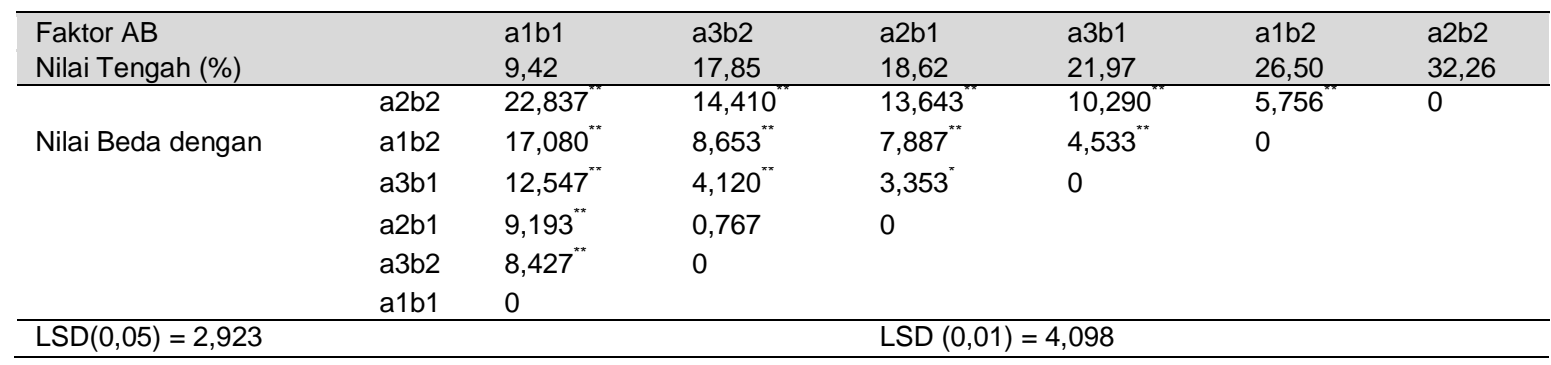

Keterangan : $\left.{ }^{* *}\right)$ berbeda sangat nyata

*) berbeda nyata

Tabel 3. Nilai Rata-Rata Sifat Mekanik Papan Partikel Serbuk Gergajian kayu Dan Limbah Penyulingan Kulit Kayu Gemor

\begin{tabular}{|c|c|c|c|c|c|c|c|}
\hline \multirow{3}{*}{ No. } & \multirow{3}{*}{$\begin{array}{l}\text { Komposisi Serbuk } \\
\text { Gergajian Kayu Dan } \\
\text { Limbah Penyulingan } \\
\text { Kulit Kayu Gemor (\%) }\end{array}$} & \multicolumn{6}{|c|}{ Parameter Uji } \\
\hline & & \multicolumn{2}{|c|}{$\begin{array}{c}\mathrm{MoR} \\
\left(\mathrm{kg} / \mathrm{cm}^{2}\right)\end{array}$} & \multicolumn{2}{|c|}{$\begin{array}{c}\mathrm{MoE} \\
\left(\mathrm{kg} / \mathrm{cm}^{2}\right)\end{array}$} & \multicolumn{2}{|c|}{$\begin{array}{c}\text { Keteguhan Tarik } \perp \\
\text { Permukaan }\left(\mathrm{kg} / \mathrm{cm}^{2}\right)\end{array}$} \\
\hline & & $\begin{array}{l}\text { Kanji } \\
\text { (b1) }\end{array}$ & $\begin{array}{l}\text { PVAc } \\
\text { (b2) }\end{array}$ & $\begin{array}{l}\text { Kanji } \\
\text { (b1) }\end{array}$ & $\begin{array}{l}\text { PVAc } \\
\text { (b2) }\end{array}$ & $\begin{array}{l}\text { Kanji } \\
\text { (b1) }\end{array}$ & $\begin{array}{l}\text { PVAc } \\
\text { (b2) }\end{array}$ \\
\hline 1. & $50: 50(a 1)$ & 18,54 & 11,03 & 137,46 & 139,61 & 4,36 & 1,09 \\
\hline 2. & $60: 40(a 2)$ & 19,37 & 18,71 & 351,50 & 338,33 & 2,13 & 1,51 \\
\hline 3. & $70: 30(a 3)$ & 27,55 & 21,87 & 310,29 & 314,88 & 4,11 & 3,18 \\
\hline
\end{tabular}


Tabel 9. Analisis Sidik Keragaman Keteguhan Patah (MoR) Papan Partikel Serbuk Gergajian Kayu dan Limbah Penyulingan Kulit Kayu Gemor

\begin{tabular}{ccccccc}
\hline $\begin{array}{c}\text { Sumber } \\
\text { Keragaman }\end{array}$ & DB & Jumlah & Kuadrat & F Hitung & \multicolumn{2}{c}{$F$ table } \\
\cline { 5 - 7 } & & Kuadrat & Tengah & & $5 \%$ & $1 \%$ \\
\hline Komposisi (A) & 2 & 298,020 & 149,010 & $33,943^{* *}$ & 3.88 & 6.93 \\
Perekat (B) & 1 & 95,957 & 95,957 & $21,858^{* *}$ & 4.75 & 9.33 \\
Interaksi (AB) & 2 & 37,646 & 18,823 & $4,288^{*}$ & 3.88 & 6.93 \\
Galat & 12 & 52,680 & 4,390 & & & \\
\hline
\end{tabular}

Keterangan : **) berpengaruh sangat nyata

*) berpengaruh nyata

Tabel 10. Uji Beda Harga Rata-rata Keteguhan Patah Papan Partikel Serbuk Gergajian Kayu dan Limbah Penyulingan Kulit Kayu Gemor

\begin{tabular}{|c|c|c|c|c|c|c|c|}
\hline Faktor AB & & $\mathrm{a} 1 \mathrm{~b} 2$ & $\mathrm{a} 1 \mathrm{~b} 1$ & $\mathrm{a} 2 \mathrm{~b} 2$ & $\mathrm{a} 2 \mathrm{~b} 1$ & a3b2 & a3b1 \\
\hline \multicolumn{2}{|l|}{ Nilai Tengah $\left(\mathrm{kg} / \mathrm{cm}^{2}\right)$} & 11,03 & 18,54 & 18,71 & 19,37 & 21,87 & 27,55 \\
\hline \multirow{4}{*}{ Nilai Beda dengan } & a3b1 & $16,523^{* *}$ & $9,013^{*}$ & $8,843^{*}$ & $8,180^{*}$ & 5,680 & 0 \\
\hline & a3b2 & $10,843^{*}$ & 3,333 & 3,163 & 2,500 & 0 & \\
\hline & $\begin{array}{l}\text { a2b1 } \\
\text { a2b2 }\end{array}$ & $\begin{array}{l}8,343^{*} \\
7,510^{*}\end{array}$ & $\begin{array}{l}0,833 \\
0,170\end{array}$ & $\begin{array}{r}0,663 \\
0\end{array}$ & 0 & & \\
\hline & $\begin{array}{l}a 1 b 1 \\
a 1 b 2\end{array}$ & $\begin{array}{r}7,510^{*} \\
0 \\
\end{array}$ & 0 & & & & \\
\hline \multicolumn{4}{|c|}{$\operatorname{LSD}(0,05)=7,810$} & \multicolumn{3}{|c|}{$\operatorname{LSD}(0,01)=10,950$} & \\
\hline
\end{tabular}

Keterangan : $\left.{ }^{* \star}\right)$ berbeda sangat nyata

${ }^{*}$ ) berbeda nyata

Tabel 11. Analisis Sidik Keragaman Keteguhan Lentur (MoE) Serbuk Gergajian Kayu dan Limbah Penyulingan Kulit Kayu Gemor

\begin{tabular}{ccrrrrr}
\hline $\begin{array}{c}\text { Sumber } \\
\text { Keragaman }\end{array}$ & DB & $\begin{array}{c}\text { Jumlah } \\
\text { Kuadrat }\end{array}$ & $\begin{array}{r}\text { Kuadrat } \\
\text { Tengah }\end{array}$ & F Hitung & \multicolumn{2}{c}{ F table } \\
\hline Komposisi (A) & 2 & 147858,544 & 73929,272 & $6,557^{*}$ & 3.88 & 6.93 \\
Perekat (B) & 1 & 20,651 & 20,651 & 0,002 & 4.75 & 9.33 \\
Interaksi (AB) & 2 & 277,749 & 138,875 & 0,0012 & 3.88 & 6.93 \\
Galat & 12 & 135288,034 & 11274,003 & & &
\end{tabular}

Keterangan : **) berpengaruh nyata

Tabel 12. Uji Beda Harga Rata-rata Keteguhan Lentur Papan Partikel Serbuk Gergajian Kayu dan Limbah Penyulingan Kulit Kayu Gemor

\begin{tabular}{llrrr}
\hline Faktor A & \multicolumn{1}{c}{ a1 } & a2 & a3 \\
\hline Nilai Tengah $\left(\mathrm{kg} / \mathrm{cm}^{2}\right)$ & & 138,54 & 312,59 & 344,92 \\
\hline \multirow{3}{*}{ Nilai Beda dengan } & a3 & $206,38^{*}$ & 32.33 & 0 \\
& a2 & 174,05 & 0 & \\
& a1 & 0 & & \\
\hline LSD $(0,05)=188,91$ & & & & LSD $(0,01)=264,85$ \\
\hline
\end{tabular}

Keterangan : *) berbeda nyata 
Papan Partikel dari Serbuk Kayu dan Limbah Penyulingan Kulit Kayu Gemor ....Budi Tri Cahyana

Tabel 13. Analisis Sidik Keragaman Keteguhan Tarik Papan Partikel Serbuk Gergajian Kayu Dan Limbah Penyulingan Kulit Kayu Gemor

\begin{tabular}{ccccccc}
\hline $\begin{array}{c}\text { Sumber } \\
\text { Keragaman }\end{array}$ & DB & $\begin{array}{c}\text { Jumlah } \\
\text { Kuadrat }\end{array}$ & $\begin{array}{c}\text { Kuadrat } \\
\text { Tengah }\end{array}$ & F Hitung & \multicolumn{2}{c}{$F$ table } \\
\cline { 6 - 8 } Komposisi (A) & 2 & 10,029 & 5,014 & $22,982^{* *}$ & 3.88 & 6.93 \\
Perekat (B) & 1 & 11,568 & 11,568 & $53,020^{* *}$ & 4.75 & 9.33 \\
Interaksi (AB) & 2 & 6,297 & 3,148 & $14,431^{* *}$ & 3.88 & 6.93 \\
Galat & 12 & 2,618 & 0,218 & & & \\
\hline
\end{tabular}

Keterangan : ${ }^{* *}$ ) berpengaruh sangat nyata

Tabel 14. Uji Beda Harga Rata-rata Keteguhan Tarik Papan Partikel Limbah Serbuk Gergajian Kayu dengan Limbah Penyulingan Kulit Kayu Gemor

\begin{tabular}{|c|c|c|c|c|c|c|c|}
\hline \multirow{3}{*}{$\begin{array}{l}\text { Faktor AB } \\
\text { Nilai Tengah }\left(\mathrm{kg} / \mathrm{cm}^{2}\right)\end{array}$} & & $\mathrm{a} 1 \mathrm{~b} 2$ & $\mathrm{a} 2 \mathrm{~b} 2$ & $\mathrm{a} 2 \mathrm{~b} 1$ & a3b2 & $a 3 b 1$ & $a 1 b 1$ \\
\hline & & 1,09 & 1,51 & 2,13 & 3,18 & 4,11 & 4,36 \\
\hline & $a 1 b 1$ & 3,267 & 2,847 & $2,23^{*}$ & $1,173^{m}$ & 0,2467 & 0 \\
\hline \multirow[t]{5}{*}{ Nilai Beda dengan } & a3b1 & $3,020^{* *}$ & 2,600 & $1,983^{* *}$ & $0,927^{*}$ & 0 & \\
\hline & a3b2 & $2,093^{* x}$ & $1,673^{* *}$ & $1,057^{*}$ & 0 & & \\
\hline & a2b1 & $1,037^{*}$ & 0,617 & 0 & & & \\
\hline & $\mathrm{a} 2 \mathrm{~b} 2$ & 0,420 & 0 & & & & \\
\hline & a1b2 & 0 & & & & & \\
\hline \multicolumn{4}{|c|}{$\operatorname{LSD}(0,05)=0,831$} & \multicolumn{4}{|c|}{$\operatorname{LSD}(0,01)=1,165$} \\
\hline
\end{tabular}

Keterangan : ${ }^{* *}$ ) berbeda sangat nyata

*) berbeda nyata 
